\title{
Status survey of slender loris Loris tardigradus lydekkerianus in Dindigul, Tamil Nadu, India
}

\author{
Mewa Singh, Donald G. Lindburg, A. Udhayan, M. Anand Kumar and H. N. Kumara
}

\begin{abstract}
A survey of the slender loris Loris tardigradus, a Vulnerable primate, was carried out in the Dindigul Forests of Tamil Nadu, India, in 1996 in order to assess prevalence. Lorises were found in high densities in the open Euphorbia scrub forests and in crop lands nearby. Although most often seen in bushes and Acacia trees, the species uses a wide variety of vegetation and substrates. Individuals were found mostly at an altitude of $300-500 \mathrm{~m}$.
\end{abstract}

Body measurements taken on sample animals revealed that the population belongs to the subspecies $L$. $t$. lydekkerianus. Conservation measures for the species in this region include additional surveys and evaluation of prospects for establishing a slender loris sanctuary.

Keywords Loris conservation, loris habitat, loris morphological traits, loris prevalence, slender loris.

\section{Introduction}

The slender loris Loris tardigradus Linnaeus, 1758 inhabits southern India and Sri Lanka. The Indian population is distributed approximately from the Tapti and Godavari Rivers southward to the tip of the subcontinent. Six different subspecies have been recognized throughout its range (Ellerman \& MorrisonScott, 1951). In India, L. t. malabaricus Wroughton, 1917 inhabits the wet forests of the Western Ghats, and $L$. $t$. lydekkerianus Cabrera, 1908 is found in the relatively dry shrub jungles of the Eastern Ghats (Roonwal \& Mohnot, 1977; Schulze and Meier, 1995; Fig. 1). Four subspecies are reported for Sri Lanka (Hill, 1953; Petter \& Hladik, 1970), but according to Jenkins (1987), existing classifications of lorises cannot be said to be final. Schulze \& Meier (1995) confirmed, after breeding slender lorises in captivity for several years, that subspecific differentiation is often difficult as a result of large inter-individual variations in colour and size within subspecies.

No systematic surveys of the distribution of the two Indian subspecies have been conducted. Existing information is based on only a few sample specimens collected over the past 100 years or so. It is even

Mewa Singh, A. Udhayan, M. Anand Kumar and H. N. Kumara Psychology Department, University of Mysore, Mysore, India. E-mail: msingh@giasbga.vsnl.net.in

Donald G. Lindburg (corresponding author), Center for Reproduction of Endangered Species, Zoological Society of San Diego, PO Box 551, San Diego, CA 92112, USA

E-mail: dlindburg@sandiegozoo.org

Received 14 August 1997. Accepted 18 June 1998 doubtful whether the type locations of these specimens were correctly reported. The only report available regarding the distribution of lorises in coastal Karnataka and the Mysore plateau (Devaraj Sarkar et al., 1981) mentions neither anything about subspecies nor indicates the number of animals sighted or relative densities in different areas.

Because the slender loris is classified as Vulnerable (IUCN, 1996), it is essential to obtain as much information as possible on its status in wild habitats. The present survey was undertaken as a first step in assessing the status of an Eastern Ghats population.

\section{Location and physical features of the surveyed area}

Our survey was conducted in the eastern part of Dindigul District, State of Tamil Nadu, southern India, in the Ayyalur, Sirumalai, Nattam and Alagar Hills forest ranges, and the Ayyalur Interface Forestry Division (Fig. 2). All fall roughly between $77^{\circ} 54^{\prime}-78^{\circ} 17^{\prime} \mathrm{E}$ and $10^{\circ} 4^{\prime}-10^{\circ} 40^{\prime} \mathrm{N}$. The altitude in this region ranges from about $250 \mathrm{~m}$ a.s.l. in the plains to about $1350 \mathrm{~m}$ a.s.l. at Sirumalai Hill. The climate is generally hot and dry, and most of the area is drought prone. Rainfall is received primarily from the north-east monsoon and is concentrated during the months of September to November.

\section{Vegetation of the survey area}

Although there are no forestry operations in this region at present, the area has been worked in the past for commercial purposes. As a result, most of the existing 


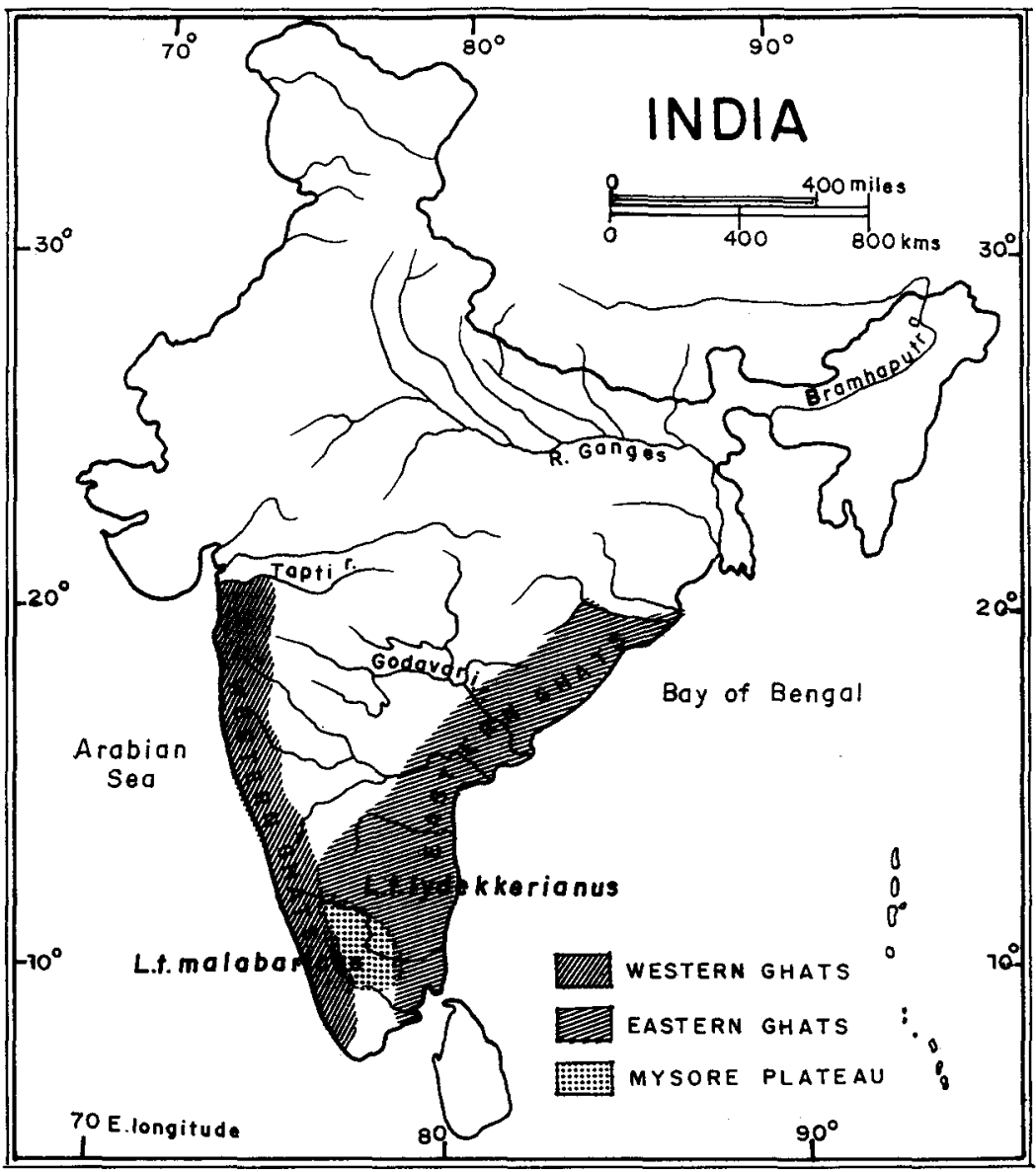

Fig. 1 Map showing the Eastern and Western Ghats, the Mysore Plateau and the approximate distribution of Loris tardigradus lydekkerianus and L. t. malabaricus. forests are secondary or degraded. The predominant forest types can be described as follows: southern tropical secondary moist mixed deciduous (Type 3B-C2 251); southern dry mixed deciduous (Type 5A/C3); carnatic umbrella thorn (Type 6A/C2); and southern Euphorbia scrub (Type 6A/C2/DS2; types from Champion \& Seth, 1968). Tree genera occurring in varying degrees in these forest types are: Anogeissus, Acacia, Pterocarpus, Albizzia, Dalbergia, Santalum, Terminalia, Azadirachta, Tamarindus, Canthium, Euphorbia, Caparis, Dodonea, Cassia, Aristida and Pterolobium. The understorey includes shrubs of Carissa, Zyziphus, Randia, Lantana, Pterolobium, Acacia, Cassia, Dodonea and Euphorbia.

\section{Methods}

The present work was carried out during November and December 1996. The survey was restricted to the eastern part of Dindigul District in the forest ranges mentioned earlier. Because the forests of this region vary from open scrub to dense deciduous forests, the survey areas were divided into five habitat types (Table 1).

The following facts were considered in designing the survey: (i) the area to be covered was fairly large; (ii) only a short period of time for survey work was available; and (iii) lorises in the area were known to be active at night. It was decided, therefore, to concentrate primarily on the presence/absence of lorises in the different types of forest, using a vehicle to travel through as many areas as possible in the time available. Whenever possible vehicular survey was supplemented by walks along pre-existing forest trails where a vehicle could not be taken. The distance walked amounted to $21.5 \mathrm{~km}$. No fixed point transect method was employed. For this initial effort no attempt was made to determine overall density or total population size.

Most of the area had a good network of roads and motorable tracks. Because the region is characterized by gentle hills, large patches of the forests on hill slopes were visible from these roads/tracks. The sightings of the animals were made by a party of 4-6 persons flashing powerful lights in all directions from the bonnet of a jeep. Travel was at a speed of $5-10 \mathrm{~km} / \mathrm{h}$. The presence of animals was determined by the orange reflection from the eyes when contacted by light. If there was ever a doubt that another animal had been mistaken for a slender loris the 'sighting' was either 
Fig. 2 Forested areas in the eastern part of the Dindigul District in which the survey was conducted.

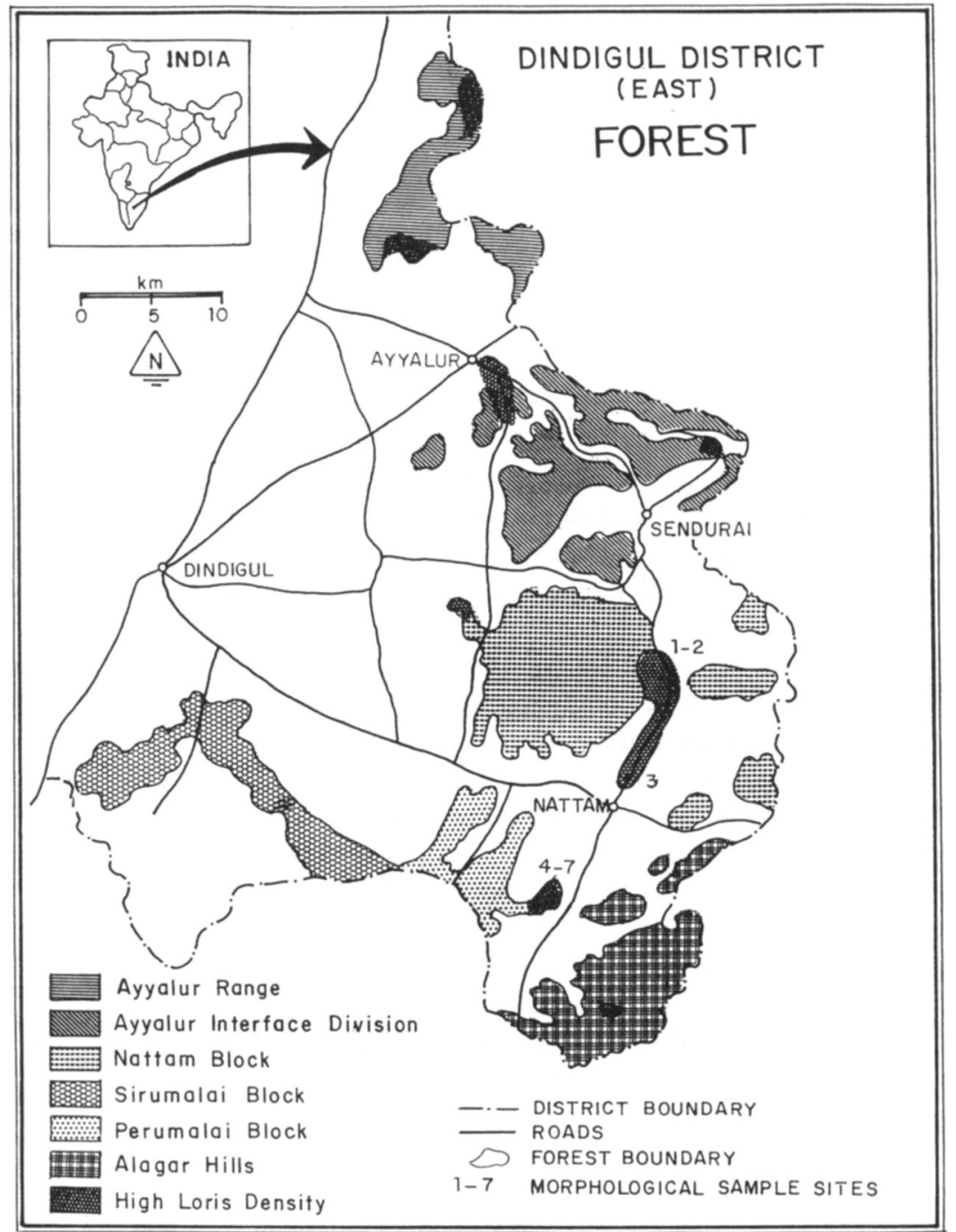

discarded or the animal was approached on foot and the identity of the species determined. The total distance walked and motored amounted to about $280 \mathrm{~km}$. The surveys were conducted from 18.00 to $06.00 \mathrm{~h}$.

Because subspecies identification in this area was unknown, diagnostic body measurements were taken on seven representative animals (three adult males, two adult females, one subadult male, one unsexed infant). Subjects were restrained by hand to obtain body measurements and weights using standard sliding callipers and a sensitive weighing balance. Limb and body lengths required full stretching of the parts to be measured, and land marks were palpated through the skin. The following data were obtained:

Body weight: Taken in $\mathrm{g}$ (rounded to $1 / 10$ th of a $\mathrm{g}$ ) Body length: From tip of snout to the vent $(\mathrm{cm})$
Leg length: From tip of femur to tip of the longest digit $(\mathrm{cm})$

Foot length: From tip of calcaneous to tip of the longest digit $(\mathrm{cm})$

Arm length: From tip of humerus to tip of the longest digit $(\mathrm{cm})$

Hand length: From wrist articulation to tip of the longest digit $(\mathrm{cm})$

Head length: Distance from mid-orbital (frontal) to tip of occiput $(\mathrm{cm})$

Head width: Distance between mastoid bones $(\mathrm{cm})$

Chest girth: Circumference at breast height $(\mathrm{cm}$; using a cloth tape)

\section{Results and discussion}

\section{Loris prevalence in different survey blocks}

Survey results from the different administrative blocks 
Table 1 Number of lorises sighted in different habitat types

\begin{tabular}{lccc}
\hline & & \multicolumn{2}{c}{ No. of animals sighted } \\
\cline { 3 - 4 } Habitat type & $\begin{array}{l}\text { Distance walked/motored } \\
(\mathrm{km})\end{array}$ & Total & Per km \\
\hline Dense Thorn Forest & 21 & 0 & 0 \\
Southern Mixed Deciduous Forest & 28 & 18 & 0.6 \\
Carnatic Umbrella Thorn and Euphorbia Open Scrub Forest & 32 & 116 & 3.6 \\
Crop lands close to forest & 40 & 111 & 2.8 \\
Crop lands away from forest & 159 & 68 & 0.4 \\
Total & 280 & 313 & 1.1 \\
\hline
\end{tabular}

revealed that the loris is distributed throughout the district, although undoubtedly in varying densities. Distribution appeared to be most uniform in the Ayyalur Interface Forestry Division, followed by Ayyalur Range and the eastern side of Karandamalai in Nattam Block (Fig. 2). In areas south of Nattam, the population was clumped, i.e. there were long gaps between sightings. Agriculture north of Nattam is rain fed, and fields, although numerous, are interspersed among the forested hills, permitting a continuous distribution of the loris population. On the other hand, the distributional gaps south of Nattam occur in an area where farming is more intensive (and canal-irrigated in many parts), with a lower density of trees. The loris populations, therefore, have become clumped in this part of the region.

High loris densities were found at certain locations in nearly all blocks. For example, a daytime sighting of six animals (including two adult males, two adult females and two infants) occurred within c. $75 \mathrm{~m}$ in Acacia planifrons trees on a small hillock $5 \mathrm{~km}$ south of Nattam. In Alagar Hills, four animals were spotted within $c$. $50 \mathrm{~m}$. Petter \& Hladik (1970) concluded from studies in Sri Lanka that in areas with the highest density, the spacing between individual animals would be about $100 \mathrm{~m}$, which also roughly corresponds to the 1-ha home range of the animal. The density of lorises, at least in many patches of Dindigul forests, appears to be much higher than in Sri Lanka.

\section{Lorises in different habitat types}

Surveyed areas were further divided into habitat types, irrespective of administrative block, because each block had more than one forest type. Sightings relative to habitat types are presented in Table 1 . The highest frequency of sightings $(3.6 / \mathrm{km})$ was in the umbrella thorn forests and degraded Euphorbia open scrub. Crop lands close to the forest also yielded a relatively high frequency of sightings $(2.8 / \mathrm{km})$. Foot surveys of over $21 \mathrm{~km}$ through dense thorn forests resulted in no sightings at all. In spite of being nearly impenetrable, thorn forests could be scanned from the hill slopes at many places. Therefore, the conclusion that infrequent sightings in dense scrub are due to low visibility may not be valid.

The data strongly indicate that relatively open forest and adjoining crop lands are the preferred habitats of lorises. There could be several reasons for this: (i) the forest provides a more continuous substrate, which lorises require because they never leap from one tree to another; (ii) there are a number of water sources available in such areas; and (iii) the forests are degraded, and the crop lands are either cultivated or have mango or tamarind plantations, providing a high density of insects and occasional fruit for lorises. In contrast, mixed deciduous and dense forests may provide a continuous canopy but low insect populations, and the crop lands beyond the forest edge may provide high insect populations but a discontinuous canopy and inadequate shelter.

\section{Other features of loris sightings}

Different species of acacia (A. planifrons, A. sundra, $A$. latronum, A. pennata), tamarinds Tamarindus indica, and a variety of shrubs and undergrowth (including Zyziphus spp., Indigofera spp., Acacia intsia, Pterolobium spp. and Euphorbia spp.), were found to be the most preferred vegetation types used by lorises, accounting for 31, 12.8 and 16 per cent of all sightings, respectively. However, because of their relatively dense foliage, sightings in trees such as the neem Azadirachta indica and mango Mangifera indica might have been missed. This point requires further investigation because both support high densities of insects. Lorises were sighted, although at very low frequencies, in eucalyptus trees, and in date and coconut palms, all of which have hardly any low-level branches. It therefore appears that the loris uses a wide variety of vegetation, but may occur predominantly in those types that support high insect densities. Where height above ground was noted $(n=252)$, nearly 93 per cent of sightings were below $6 \mathrm{~m}$, but all levels were used. These were sightings at 


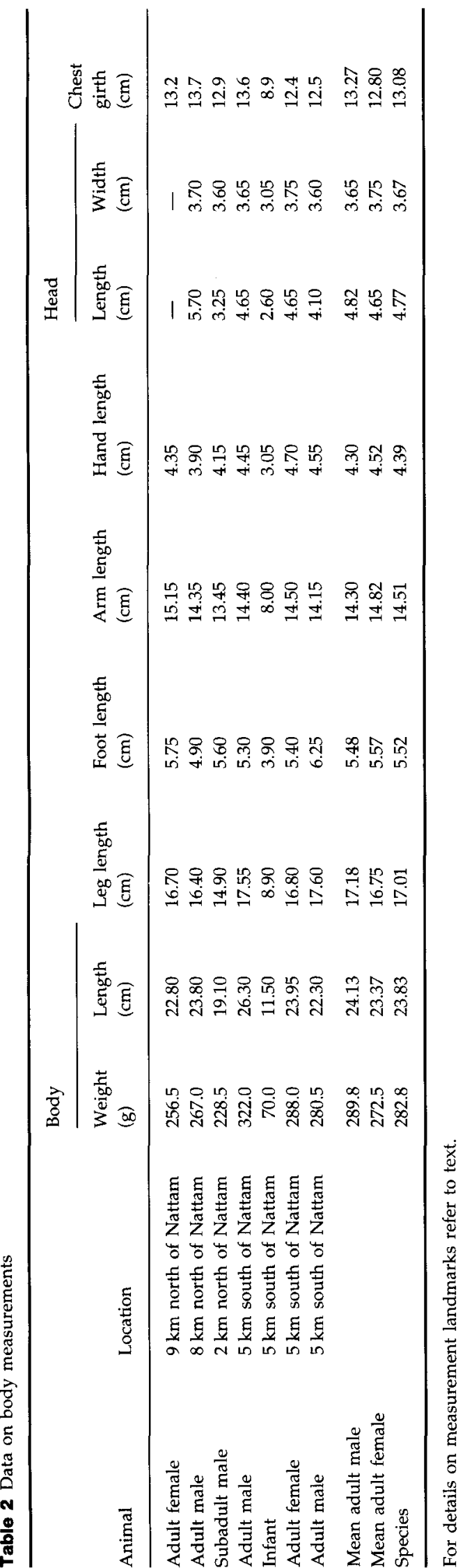

night, when the animals were most active. It is possible that they ascend to locations above $6 \mathrm{~m}$ for daytime rest.

The areas traversed during this survey ranged in altitude from $c .250$ to $1300 \mathrm{~m}$. Most sightings ( $>90$ per cent) were in areas below $500 \mathrm{~m}$. Only one animal, at Sirumalai Hill, was found at an altitude above $1000 \mathrm{~m}$. This observation corresponds with data from sightings according to habitat type, i.e. degraded scrub forests in this area are generally found at altitudes below $500 \mathrm{~m}$, and the mixed deciduous forests begin from this altitude.

\section{Morphological traits}

Body measurements (Table 2) were taken primarily to determine subspecies identity. The mean body weight $(282.8 \mathrm{~g})$ and length (including the head, $23.83 \mathrm{~cm}$ ) clearly indicate that this population belongs to the subspecies L. t. lydekkerianus, i.e. it is significantly larger than the sizes given for L. t. malabaricus (Schulze \& Meier, 1995). Additional measurements are reported in Table 2 for use in future comparisons with samples from other populations. As pointed out by Schulze \& Meier (1995), and also on the basis of the present data, it can be stated that the slender loris is characterized by considerable inter-individual variation in weight as well as in the dimensions of various body parts. The buff colour of the dorsal pelage with dark medial stripe, along with white ventrum in all seven animals measured, further confirms the subspecific identity of this population.

One of the animals taken for morphological measurements was a subadult male, probably about 7-8 months old. We also came across at least four infants, which we estimated on the basis of their body size to be about 1 month old. These observations may lead to an inference that the slender loris has two birth seasons in the year. According to Rao (1927), birth seasons may occur during March-April and October-November.

\section{Suggestions for further research in the Dindigul region}

\section{Densities and distribution patterns}

A more detailed survey should be conducted in the different forest blocks and habitat types in order to obtain quantitative data on densities and distribution patterns. Although on occasion we observed males to move as far as $100 \mathrm{~m}$ during a single night's activity, females seldom moved more than a few metres. Therefore, the best technique for further survey would be the 'fixed point line transects' suggested by Burnham et al. (1980). 
Similar habitat to the west of our site should also be surveyed. Areas to the south-west should be investigated in the interest of determining the geographical range of L. t. lydekkerianus. This western edge of the Eastern Ghats is separated by only about $10 \mathrm{~km}$ from the easternmost projection of the Western Ghats. We did not sight any lorises on the nearby slopes of the Western Ghats, but further survey work would aid in determining the extent and nature of the gap between L. t. lydekkerianus, whose range ends at the southern and western slopes of Sirumalai, and L. t. malabaricus, whose range begins somewhere in the relatively wet forests of the Western Ghats.

\section{Ecological and behavioural study}

A fairly long-term study (at least for 2 years) of the ecology and behaviour of lorises in the Dindigul region is desirable in order to increase knowledge of habitat quality, feeding habits, ranging patterns, demographic structure, birth seasonality, birth and death rates, infant development and social behaviour. Because the slender loris is nocturnal and solitary, individuals are not easily identified. This requirement, and reduction in search time, could be achieved by radio-collaring, and it is strongly recommended that at least 25 individuals be collared for intensive behavioural observations.

\section{Threats}

Threats to the loris population in Dindigul must also be identified. We noted several cases of mortality from road accidents. Once the severity of this threat is established, it may be possible to minimize vehicular traffic during the night, at least on some critical country side roads (if not the highways). Speed breakers could also be established at those points where the animals often cross the road.

Illegal trapping of lorises for 'medicinal' purposes was also noted. The extent of such illegal trapping must be established before measures can be taken to stop it, as well as to educate people against the unfounded belief that loris eyes have medicinal value. Extraction of wood for fuel, especially from forests closest to villages, poses an additional threat in the form of critical habitat loss. Extraction of fuelwoods could be reduced by declaring the area a sanctuary. Armed with information on densities, distribution patterns, ecology, behaviour and human pressures on the population, one could then design scientifically based conservation and management plans for this rare species.

\section{Recommendations}

Although more intensive work is required on the Dindigul population, it is not too early to think of this part of the forest as having potential as a 'Slender Loris Wildlife Sanctuary'. Several arguments can be offered in favour of this idea and these are listed below.

- The slender loris is a threatened species, classified under Schedule I of the Indian Wildlife Act, 1972, and therefore requires special protection.

- Whereas a number of forests have been set aside for the exclusive conservation of many other Schedule I animals in India, there has never been an emphasis on loris conservation.

- The Dindigul region harbours a very high density of slender lorises. This population assumes additional significance in light of the distributional ranges of the two subspecies. The Dindigul subspecies is found primarily in the Eastern Ghats and Dindigul (East) constitutes the south-western edge of this hill range. Although surveys are required in other regions of the Eastern Ghats, the possibility exists that, compared with other areas, the Dindigul region may have the highest density of lorises.

- There are no ongoing forestry operations in this region. If the Reserved Forests at Dindigul are declared a sanctuary, the Government does not stand to lose forestry revenues.

- The different forest ranges in the area are separated by private land holdings. If an area is to be declared a wildlife sanctuary, the ranges need to be connected. This often causes problems because the private lands cannot be easily acquired, especially if they are cultivated. But this problem causes no concern in the case of the conservation and management of lorises. The Dindigul forests are already well managed and lorises are found throughout the area, including on the cultivated/uncultivated private lands. Unlike large mammals, which require corridors, this may not be a serious requirement for loris conservation, because they can exist in cultivated lands close to the forest. Even without a real forest corridor, these populations can maintain continuity for gene flow. There is little danger of populations becoming separated into small breeding units. All that is required is some minimum tree cover through the non-forested lands.

- Because the loris primarily feeds on insects and other invertebrates, and normally would not feed on crop and garden produce, there is no threat of humanloris conflict. As a result, the people in and around the sanctuary may easily tolerate the presence of lorises. 
- The legal status of being in a wildlife sanctuary may provide more protection for this Vulnerable species. The presence of a small population of gaur Bos frontalis, also classified as Vulnerable by IUCN (1996), in the area, would lend support to the establishment of a sanctuary.

\section{Acknowledgements}

The field data collection and the preparation of this report involved the active participation of Mridula Singh, Lancy D'Souza, M. Salahuddin and T. R. Shashidhar. We gratefully acknowledge the support received from the Tamil Nadu Forest Department at all stages. Field expenses incurred during this work were covered by the Zoological Society of San Diego.

\section{References}

Burnham, K.P., Anderson, D.R. \& Laake, J.L. (1980) Estimation of density from line-transect sampling of biological populations. Wildlife Monographs, 72, 1-202.

Champion, H. \& Seth, S.K. (1968) A Revised Survey of the Forest Types of India. Manager of Publications, Government of India, Delhi.

Devaraj Sarkar, H.B., Murali, S., Prasad, D.T., Shekarappa, B.M. \& Vijayalakshmi, V. (1981) The population and distribution of the slender loris (Loris tardigradus) in Karnataka State. Tigerpaper, 8, 7-10.

Ellerman, J.R. \& Morrison-Scott, T.C.S. (1951) Checklist of Palaearctic and Indian Mammals, 1758-1946. British Museum, London.
Hill, W.C.O. (1953) Primates. Comparative Anatomy and Taxonomy: 1 Strepsirhini. Edinburgh University Press, Edinburgh.

IUCN (1996) 1996 IUCN Red List of Threatened Animals. IUCN-The World Conservation Union, Gland Switzerland.

Jenkins, P.D. (1987) Catalogue of Primates in the British Museum (Natural History). Part IV: Suborder Strepsirhini. British Museum (Natural History), London.

Petter, J.J. \& Hladik, C.M. (1970) Observations sur le domaine vital et la densité de population de Loris tardigradus dans les forêts de Ceylon. Mammalia, 34, 394-409.

Rao, C.R.N. (1927) Observations on the habits of the slow loris Loris lydekkerianus. Journal of the Bombay Natural History Society, 32, 206-208.

Roonwal, M.L. \& Mohnot, S.M. (1977) Primates of South Asia: Ecology, Sociobiology, and Behavior. Harvard University Press, Cambridge, MA.

Schulze, H. \& Meier, B. (1995) The subspecies of Loris tardigradus and their conservation status: a review. In Creatures of the Dark: the Prosimians (eds L. Altman, G. A. Doyle and M. K. Izard), pp. 191-209. Plenum Publishing, New York.

\section{Biosketches}

Mewa Singh is a psychologist and a primatologist who has been working on the ecology, behaviour, conservation and management of wildlife, particularly non-human primates, in India for over two decades. His other current research interests include conservation of lesser known species in neglected habitats. 